\title{
HOW IMPORTANT ARE GENERAL EQUILIBRIUM MODELS FOR SMALL OPEN ECONOMIES - A CASE OF CROATIA
}

\author{
Marinko ŠKARE, Saša STJEPANOVIĆ \\ University of Jurja Dobrila, Department of Economy and Tourism "Dr. Mijo Mirkovic", \\ Preradoviceva 1/1, 52100 Pula, Croatia
}

Received 01 March 2012; accepted 06 August 2012

\begin{abstract}
This paper develops a general equilibrium model for the Republic of Croatia to evaluate CGE model use in macroeconomic management and forecasting. Since Croatia is a small open country subject to large external shock and growth constraints efficient macroeconomic management framework is fundamental. The lack of data prevents to follow historic economic variables over a longer period of time, which is why CGE models look as possible solution. CGE models use calibration to solve the problem of missing most macroeconomic variables. After developing the model, we use it to run different scenarios for economic policies using a CGE model for Croatia. Results show that CGE model can be an important instrument for policy makers in running macroeconomic policies for small open countries.
\end{abstract}

Keywords: policy modeling, general equilibrium models, small-open economies, external shocks.

Reference to this paper should be made as follows: Škare, M.; Stjepanović, S. 2013. How important are general equilibrium models for small open economies - a case of Croatia, Technological and Economic Development of Economy 19(2): 331-349.

JEL classification: $\mathrm{C} 68, \mathrm{O} 21, \mathrm{O} 40, \mathrm{P} 36$.

\section{Introduction}

How important are General Equilibrium Models for small open economies? General Equilibrium Model (GEM) represents a combination of the basic postulates of the theory of general equilibrium with data from the economy of a country. Model includes data related to supply and demand, prices, and overall balance in different markets. CGE models represent an essential tool for empirical analysis used in assessment of economic policies impact such as policy changes in tax rates, a wealth distribution, etc.

Corresponding author Marinko Škare

E-mail: mskare@efpu.hr 
Using general equilibrium models for the study of small open economies and the importance of these results is this paper key question. CGE models are widely used in small open economies of developing countries. In the literature of the developing countries, "Computable general equilibrium" (CGE) models represent an incremental improvement in the long tradition of working with programmable multi-sectoral models. CGE models simulate the interaction between different economic entities on the overall market. Optimized behavior of economic agents in the form of behavioral equations is included in the model. A behavioral equation reflects different conditions for optimizing and maximizing profits. Structure of the CGE model requires a description of the overall supply and demand in the market. In this way, the model is structural, and it shows the market mechanisms explicitly.

Assessing importance of CGE models and their role in macroeconomic policy design is the main goal of this study. CGE models are commonly used in small open economies of developing countries and are most suitable for countries like Croatia. Given the lack of a strategy and macroeconomic models, high vulnerability to external shocks, CGE models are set as one of the most adaptable solutions. Macroeconomic management in Croatia lacks in clear development strategy and decisions in economic policy are not based on any macroeconomic model. So, evaluation of the quality of CGE models is of utmost importance. Any decision in the economy should be at least simulated using CGE models before its implementation. Given the absence of macroeconomic models in Croatia, the possibility of building Croatian CGE model will be presented in this paper.

In previous research there has not been examined the ability of creating CGE models for the Croatian economy. Therefore, our work is based on a model for countries of similar size and position as Croatia.

\section{Literature review}

Because of the lack of research on the possibilities of building macroeconomic models for Croatian economy, there is no necessary literature that would provide the research basis for this paper. Thus, we have studied literature and developed CGE models from neighboring countries and those countries that have equal or similar features. Many papers and books on the subject of CGE models and their characteristics exist.

In the study of Burkhard and Mausner (2005), Dynamic General Equilibrium Modelling, theoretical assumptions of different types of forecasting models and their components is presented. Mitra-Kahn (2005) in his work explains the history of CGE models and their relation to the market economy. Devarajan et al. (1997) show the development of a simple model of general equilibrium. This model is called the 1-2-3 model or two sectoral model, which is a simplified economy of one country with two sectors and three different manufacturing goods. Senay (1998) in his work writes about Disinflation Dynamics in an Open Economy in General Equilibrium model. Baležentis et al. (2010) using MULTIMOORA find technological constraints to produce low productivity and growth in Lithuania. Podvezko and Podviezko (2010) support the idea of building a general model using a multicriteria method (PROMETHEE) for the need of studying economic phenomena. Žvirblis and Buračas 
(2010) advance a SAW multicriteria evaluation method as a possible quantitative framework for macroeconomic management. As Zavadskas and Turskis (2011) points out, current economic models mirrors the desire of using empirical approach linked to the physics science. Economic models evolve because of their appeal to represent reality as best as possible. Hsing (2011) develops a GARCH model to study the impact of major macroeconomic variables on the Croatian stock market index. Škuflić et al. (2010) in their study advice on exploring the possibility of using DEA to study a country's macroeconomic performances. Čižmešija and Petar (2010) in their study propose a holistic macroeconomic model for Croatia.

Smets and Wouters (2002) have constructed an estimated stochastic dynamic general equilibrium model of the Euro area. In this paper, they show each sector, which comprises the model, create the linear model and compare it with the VAR model. Lofgren et al. (2002) prepared a manual entitled A Standard Computable General Equilibrium (CGE) Model in GAMS. Their paper clearly shows the process of making CGE models, from creating of the Social Accounting Matrix through the mathematical foundation and the ultimate goal of making the model itself. In the paper of Mitra-Kahn (2008) the history of CGE models from Leontief until today is summarized. He explains the link between general equilibrium theory with CGE models and features related to CGE models (behavioral equations and calibration). Wing (2000) in his work, present computable equilibrium models and their use in economy wide policy analysis. Particular attention was given to the author for making SAM matrix and explaining the transition from SAM matrix to CGE model. In his work, Essama-Nssah (2004) shows how to create models of general equilibrium in the econometric program EView.

Our paper is based on previous literature (section 1), with emphasis on the Croatian economy features. In this paper, we build the first SAM matrix for Croatia. Calibration of the model and its mathematical background reflect specific conditions of the observed economy. Work results are presented in the form of forecast economic trends of important parameters in the section 3. We present quantified changes present in the economy as a response to external shocks and changes that may occur in the global economy, which inevitably affects the small-open developing countries.

\section{Data and model specification}

SAM (social accounting matrix) forms the basis for the development of CGE models. According to Huseyin (1996), social accounting matrix is simply defined as an unambiguous accounting system where every macroeconomic account is presented as a column for output and as a row for incoming bills. It is presented in the form of a square matrix with rows and columns, which together present the production and revenues generated from different institutional groups and classes, on the one hand, and the data on the consumption of these revenues on the other side. In this matrix, the revenues are shown as receipts accounts that are presented in the rows, while the costs are presented in columns. All revenues must be matched with the expenditure, and the total value of all rows must equal the total value of all columns in the matrix. 
Lange et al. (2004), define SAM as a data system, which includes social and economic data for a particular economy. The data source for the SAM derived from input - output tables, national statistics on income, household income and consumption statistics. That's why SAM is a lot wider than the input - output tables, or typical national accounts, showing much more detail about the different types of transactions in the economy. However, input - output table records economic transactions without examining the social background of participants in the transaction. SAM tries to classify different institutions according to their socio - economic situation instead of just looking at their economic functional activity.

SAM is a logical way to edit the statistical information concerning the flow of income in a particular economy of a country in a specific time period (usually one year). It provides a conceptual basis for analysis of income distribution and monitoring of economic growth in a particular environment (Llop 2012). For example, SAM displays the distribution of factor income from domestic and foreign origin, to the institutional sectors and income redistribution through these sectors. In addition, it shows the sector costs, consumption, investment and savings (Kim 2011).

SAM has two main goals: the first is to organize information on economic and social structures of a country in a given period, and the second is to provide the statistical basis for the creation of macroeconomic models that will be able to present a statistical picture of the economy, together with simulation effects that provide the intervention impact politics to economics (Akkemik 2012).

Social accounting matrix is designed as a generalized input-output table that provides a description of the entire accounting for a particular economy. However, it is important to note the difference between the input-output tables, and SAM. Input-output tables show industries interrelation through certain transactions. SAM displays transfers and transactions between different sectors in the economy, different types of businesses, governments and the rest of the world. SAM is a presentation of data from the system of national accounts, which is formed into a matrix. It takes the form of a matrix where the number of rows equals the number of columns for each category of products, production factors and economic actors. Each row shows the origins of certain economic resources that are associated with certain economic actors. Each column, show resources and their usage. Each assigned row and column shows the sectors' accounts in the economy and its spending and revenue, which must be in balance. Basic principles of accounting, equality must be respected by each sector in the economy and thus in balance. Groups of sectors in the economy are, households, governments, companies, etc. Each sector in the economy and their accounts explain in details the relationship between production structure, income distribution, financial transactions within the domestic economy, and later on financial transactions of the rest of the world (Santos 2005).

Table 1 shows theoretical SAM matrix for the Croatian economy. Based on this matrix, we develop a CGE model for Croatia (see Table 2). Data for the SAM matrix were obtained from the Central Bureau of Statistics, Ministry of Finance and the Croatian National Bank. 
Table 1. Theoretical social accounting matrix for Croatian economy

\begin{tabular}{|c|c|c|c|c|c|c|c|}
\hline & Activity & Commodity & Household & Government & Investment & World & Total \\
\hline Activity & & $\begin{array}{l}\text { Domestic } \\
\text { Sales }\end{array}$ & & & & Exports & Total Sales \\
\hline Commodity & & & $\begin{array}{l}\text { Household } \\
\text { Consumption }\end{array}$ & $\begin{array}{l}\text { Government } \\
\text { Consumption }\end{array}$ & Investment & & $\begin{array}{l}\text { Total } \\
\text { Absorption }\end{array}$ \\
\hline Household & $\begin{array}{l}\text { GDP at } \\
\text { Factor Cost }\end{array}$ & & & & & $\begin{array}{l}\text { Foreign } \\
\text { Remittances }\end{array}$ & $\begin{array}{l}\text { Household } \\
\text { Income }\end{array}$ \\
\hline Government & $\begin{array}{l}\text { Indirect } \\
\text { Taxes }\end{array}$ & Tariffs & Income Tax & & & & $\begin{array}{l}\text { Government } \\
\text { Revenue }\end{array}$ \\
\hline Savings & & & $\begin{array}{l}\text { Household } \\
\text { Savings }\end{array}$ & $\begin{array}{l}\text { Government } \\
\text { Savings }\end{array}$ & & $\begin{array}{l}\text { Foreign } \\
\text { Savings }\end{array}$ & Total Savings \\
\hline World & & Imports & & & & & $\begin{array}{l}\text { Total } \\
\text { Imports }\end{array}$ \\
\hline Total & $\begin{array}{l}\text { GDP Market } \\
\text { Prices }\end{array}$ & Total Supply & $\begin{array}{l}\text { Total House } \\
\text { Expenditure }\end{array}$ & $\begin{array}{l}\text { Government } \\
\text { Expenditure }\end{array}$ & $\begin{array}{l}\text { Total } \\
\text { Investment }\end{array}$ & $\begin{array}{l}\text { Total Foreign } \\
\text { Exchange }\end{array}$ & \\
\hline
\end{tabular}

Source: B. Essama-Nssah, "Building and running general equilibrium models in eviews".

Table 2. Numerical social accounting matrix for Croatian economy for 2010

\begin{tabular}{|c|c|c|c|c|c|c|c|}
\hline & Activity & Commodity & Household & Government & Investment & World & Total \\
\hline Activity & & 177000.47 & & & & 145971.6 & 322972.07 \\
\hline Commodity & & & 189505.8 & 37733.69 & 105316.4 & & 332555.89 \\
\hline Household & 287101.58 & & & & & -109392.11 & 177709.4 \\
\hline Government & 35870.49 & 1913.42 & -14286.63 & & & & 23497.32 \\
\hline Savings & & & 2490.26 & -14236.37 & & 117062.51 & 105316.4 \\
\hline World & & 153642 & & & & & 153642 \\
\hline Total & 322972.07 & 332555.89 & 177709.4 & 23497.32 & 105316.4 & 153642 & \\
\hline
\end{tabular}

Source: Autors calculation.

Our study describes the specification of CGE models for Croatia. Through the following equation, we describe the CGE model. On the production side of the model we find the following equations. First it is derived from the CET export function: $E=D \cdot\left(\left(\frac{C}{D}\right) \cdot \frac{1-\alpha_{x}}{\alpha_{x}}\right) \wedge\left(\frac{1}{\varphi_{x-1}}\right)$.

Consequently, domestic sales $D=I-E$. Domestic prices of exports are shown in the following form: $C=T \cdot C W+(1+t e)$. Producer prices for composite output: $P=\frac{C+E+C D+D}{I}$.

Under the production side of the model we find prices of domestic products, specifically including all taxes: $C D \cdot D=(C C \cdot Q C-P I \cdot Q I)$ and before taxation: $C P O=\frac{C D}{1+t d}$.

On the consumer side of the model we have domestic prices of imports: $P I=T \cdot C I \cdot(1+\mathrm{tm})$ and the amount bid for the composite good as defined in Armington's aggregate functions exportsand demand forlocal products: $Q C=b_{q} \cdot\left(\left(\beta_{q} \cdot Q I \wedge\left(-\rho_{q}\right)+\left(1-\beta_{q}\right) \cdot D \wedge\left(-\rho_{q}\right)\right) \wedge\left(1-\rho_{q}\right)\right.$. 
In addition on the consumer side of model import is defined from Armington's aggregate functions: $Q I=D \cdot\left(\frac{\left(\frac{C D}{P I}\right) \beta_{q}}{1-\beta_{q}}\right) \wedge\left(\frac{1}{1+\rho_{q}}\right)$ and price of composite consumer goods
$C C=\frac{(P K+P D+I N)}{Q C}$.

Government account as part of the model consists of tariffs that are shown in the following form: $C A=(\mathrm{tm} \cdot C I+T+Q I)$, indirect taxes: $I P=\left(t d \cdot \frac{C D}{1+t d} \cdot D\right)$ and household taxes: $P K=y t x_{h h} \cdot R K$ and revenues of the government: $R D=C A+I P+P K-(t e \cdot C W \cdot T \cdot E)$.

Income and household saving in the model are shown as household income: $R K=P \cdot X S-I P+\left(T \cdot T R_{h h}\right)$ and the savings of the household: $S K=m p s_{h h} \cdot\left(1-y t x_{h h}\right) \cdot R K$ and household consumption: $P K=\left(1-m p s_{h h}\right) \cdot \frac{\left(1-y t x_{h h}\right) R K}{C C}$.

In addition to the above-mentioned parts of the model we compute the aggregate savings in the following form: $U S=S K+(T \cdot F S A V)+S D$, and we set system restrictions and conditions of confinement. Under the system constraints it is assumed full capacity of the economy and because of that the variable import is exogenous variable in the model. A restriction on domestic demand is defined implicitly through the variable $\mathrm{D}$, while the balance of the composite consumer good is defined by variable QC. In addition to the system constraints is defined fiscal balance: $S D=(R D-C C \cdot P D)$, and the balance of payments in local currency: $T \cdot F S A V=\left(P I \cdot \frac{Q I}{1+t m}-C \cdot E-\left(T \cdot T R_{h h}\right)\right)$ and savings and investment balance: $I N=\frac{U S}{C C}$ in conditions when private and government consumption are fixed (as in Essama-Nssah 2004). Below in text are presented some sector flows, prices, equilibrium conditions, identities and their equation (see Essama-Nssah 2004).

Flows:

$$
\begin{gathered}
\bar{X}=G\left(E, D^{S} ; \Omega\right) ; \\
Q^{S}=F\left(M, D^{D} ; \sigma\right) ; \\
Q^{D}=\frac{Y}{p^{q}} ; \\
\frac{E}{D^{S}}=g_{2}\left(p^{e}, p^{d}\right) ; \\
\frac{M}{D^{D}}=f_{2}\left(p^{e}, p^{d}\right) ; \\
Y=p^{x} \cdot \bar{x}+R \cdot \bar{B} .
\end{gathered}
$$


Prices:

$$
\begin{gathered}
p^{m}=R \cdot p w^{m} ; \\
p^{e}=R \cdot p w^{e} ; \\
p^{x}=g_{1}\left(p^{e}, p^{d}\right) ; \\
p^{q}=f_{1}\left(p^{m}, p^{d}\right) ; \\
R=1 .
\end{gathered}
$$

Equilibrium conditions:

$$
\begin{gathered}
D^{D}-D^{S}=0 ; \\
Q^{D}-Q^{S}=0 ; \\
p w^{m} \cdot M-p w^{e} \cdot E=\bar{B} .
\end{gathered}
$$

Identities:

$$
\begin{gathered}
p^{x} \cdot \bar{X}=p^{e} \cdot E+p^{d} \cdot D^{S} \\
p^{q} \cdot Q^{S}=p^{m} \cdot M+p^{d} \cdot D^{d} \\
Y=p^{q} \cdot Q^{d 1} .
\end{gathered}
$$

The basic model refers to one country with two producing sectors and three goods, and that is why it is called $1-2-3$ model. The two commodities that the country produces are (1) an export good, E, which is sold to foreigners and is not demanded domestically, and (2) a domestic good, $\mathrm{D}$, which is only sold domestically. The third good is an import, $\mathrm{M}$, which is not produced domestically. There is one consumer who receives all income. The country is small in world markets, facing fixed world prices for export and imports (Channing et al. 2001).

Equation (1) defines the domestic production possibility frontier, which gives the maximum achievable combinations of $\mathrm{E}$ and $\mathrm{D}$ that the economy can supply. The function is assumed to be concave and will be specified as a constant elasticity of transformation (CET) function with transformation elasticity W. The constant $\bar{X}$ defines aggregate production and is fixed. Since there are no intermediate inputs, $\bar{X}$ also corresponds to real GDP. The assumption that $\bar{X}$ is fixed is equivalent to assuming full employment of all primary factor inputs. Equation (4) gives the efficient ratio of exports to domestic output (E/D) as a function of relative prices. Equation (9) defines the price of the composite commodity and is the cost-function dual to the first-order condition, Eq. (4). The composite good price $p^{x}$ corresponds to the GDP deflator (Citanna et al. 2005).

Eq. (2) defines a composite commodity made up of D and $\mathrm{M}$, which is consumed by the single consumer. In multi-sector models, we extend it to many sectors, assuming that imports and domestic goods in the same sector are imperfect substitutes, an approach that has come to be called the Armington's assumption. We assume the composite commodity is given by

Donald Brown, Felix Kubler, Computational Aspects of General Equilibrium Theory, Springer, 2008. 
a constant elasticity of substitution (CES) aggregation function of $\mathrm{M}$ and $\mathrm{D}$, with substitution elasticity s. Consumers maximize utility, which is equivalent to maximizing $\mathrm{Q}$ in this model, and Eq. (5) gives the desired ratio of $\mathrm{M}$ to $\mathrm{D}$ as a function of relative prices. Eq. (10) defines the price of the composite commodity. It is the cost-function dual to the first-order conditions underlying Eq. (5). The price $p^{e}$ corresponds to an aggregate consumer price or cost-of-living index (Turner 2012).

Eq. (6) determines household income. Eq. (3) defines household demand for the composite good. Note that all income is spent on the single composite good. Eq. (3) stands in for the more complex system of expenditure equations found in multisector models and reflects an important property of all complete expenditure systems: The value of the goods demanded, must equal aggregate expenditure.

Price's equations define a relationship between seven prices. There are fixed world prices for $\mathrm{E}$ and $\mathrm{M}$; domestic prices for $\mathrm{E}$ and $\mathrm{M}$; the price of the domestic good $\mathrm{D}$; and prices for the two composite commodities X and Q. Eqs (1) and (2) are linearly homogeneous, as are the corresponding dual price Eqs (9) and (10). Eqs (3) to (5) are homogeneous of degree zero in prices - doubling all prices, for example, leaves real demand and the desired export and import ratios unchanged. Since only relative prices matter, it is necessary to define a numeraire price; in Eq. (11), this is specified to be the exchange rate R. Eqs (12), (13) and (14) define the market-clearing equilibrium conditions. Supply must equal demand for D and Q, and the balance of trade constraint must be satisfied. The complete model has fourteen equations and thirteen endogenous variables. The three equilibrium conditions, however, are not all independent. Any one of them can be dropped, and the resulting model is fully determined (Moore 2007).

To prove that the three equilibrium conditions are not independent, it suffices to show that the model satisfies Walras's Law (Timilsina et al. 2012). Such a model is "closed" in that there are no leakages of funds into or out of economy. First note the three identities - (15), (16) and (17) - that the model satisfies. The first two arise from the homogeneity assumptions and the third from the fact that, in any system of expenditure equations, the value of purchases must equal total expenditures. Multiplying Eqs (12) and (13) by their respective prices, the sum of Eqs (12), (13), and (14) equals zero as an identity. Given these identities, simple substitution will show that if Eqs (12) and (13) hold, then so must (14) (Devarajan et al. 1997).

\section{Empirical results}

From CGE models created for Croatian economy, we can observe the impact of various external shocks to certain variables in the Croatian economy. The first prerequisite for a successful model is set to bring all the variables in the model balance. After that, we are observing the impact of changes of external shocks on the balance. From the above model, we consider the variable GDP, and how it affects changes in growth or a decline in the exchange rate and changes in inflation trends.

Table 3 shows the scenario of exchange rate movements for US dollar expressed in Kuna, and the impact of exchange rate movements in GDP. 
In this scenario we observe a strengthening exchange rate of Kuna against the US dollar and the assessment of impact of the strengthening to the GDP, as shown in the following chart (Fig. 1).

Table 3. Dollar exchange rate depreciation impact on GDP

\begin{tabular}{|c|c|c|c|c|c|c|c|c|c|c|}
\hline & & 2010 & & 2011 & & 2012 & & 2013 & & 2014 \\
\hline Exchange rates & $\$$ & 5.54 & $\$$ & 5.34 & $\$$ & 4.80 & $\$$ & 4.32 & $\$$ & 4.10 \\
\hline GDP (in millions of Kuna) & \multicolumn{2}{|c|}{$350,460.00$} & \multicolumn{2}{|c|}{$300,085.00$} & \multicolumn{2}{|c|}{$321,675.00$} & \multicolumn{2}{|c|}{$339,002.00$} & \multicolumn{2}{|c|}{$301,547.00$} \\
\hline
\end{tabular}

Source: Autors calculation
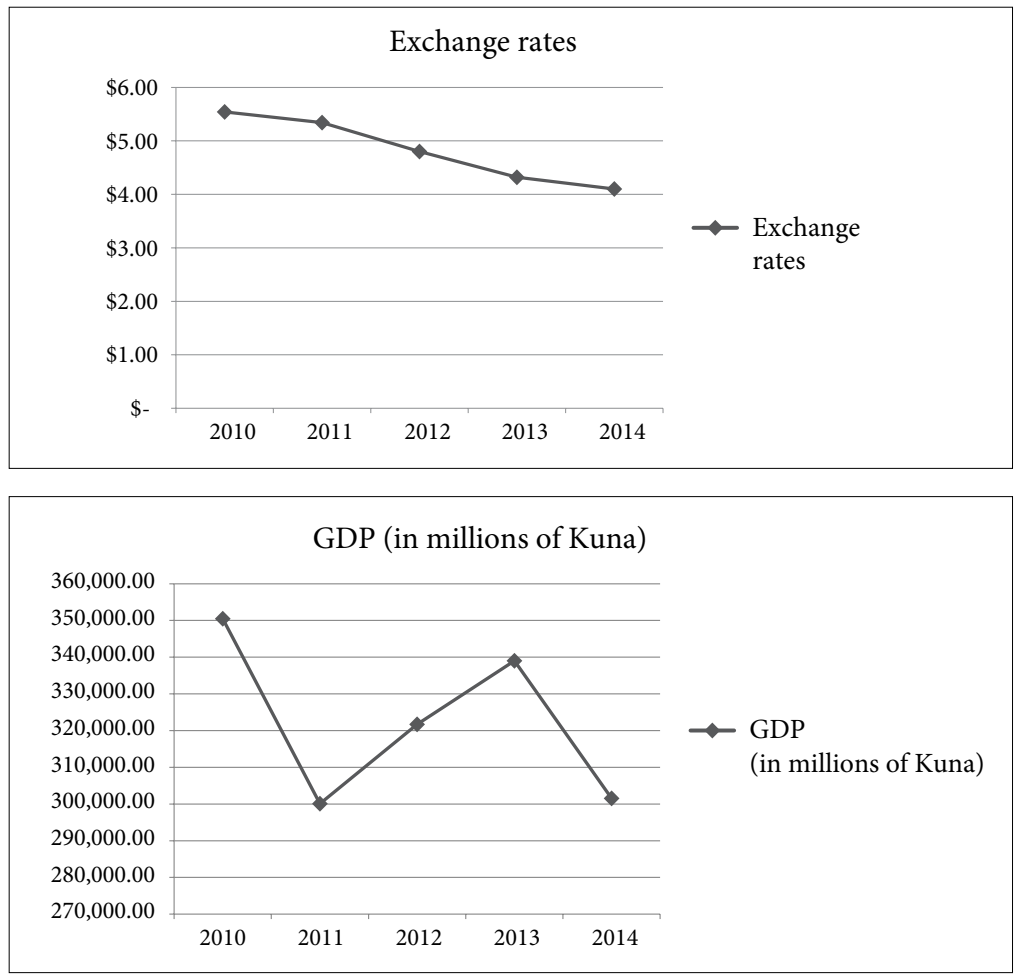

Fig. 1. Dollar exchange rate depreciation scenario impact on GDP. Source: Autors calculation

Table 3 shows that the case of strengthening exchange rate of Kuna against the US dollar leads to reduction of GDP. In this case, we observe the movement of GDP in the range of years from 2010 to 2014. From this case, we can conclude that there is a strong correlation of these two variables that affect the very course of Croatian economy. Large reduction in GDP occurred in the first year, 2011, after that regardless of further strengthening exchange rate of Kuna against the US dollar, GDP remains constant. After the initial shock, the economy adapts to new conditions and is ready for a further decline in the exchange rate. 
Table 4 shows the scenario of exchange rate movements US dollar expressed in Kuna, and the impact of exchange rate movements in GDP. In this case we simulate depreciation of Kuna against the US dollar, and follow the impact of exchange rate movements on GDP (see Fig. 2).

Table 4. Kuna exchange rate depreciation scenario impact on GDP

\begin{tabular}{|c|c|c|c|c|c|c|c|c|c|}
\hline & & 2010 & & 2011 & & 2012 & & 2013 & 2014 \\
\hline Exchange rates & $\$$ & 5.24 & $\$$ & 5.98 & $\$$ & 6.42 & $\$$ & 6.98 & 7.15 \\
\hline GDP (in millions of Kuna) & & 35.00 & & 574.00 & & 725.00 & & 173.00 & $245,879.00$ \\
\hline
\end{tabular}

Source: Autors calculation.
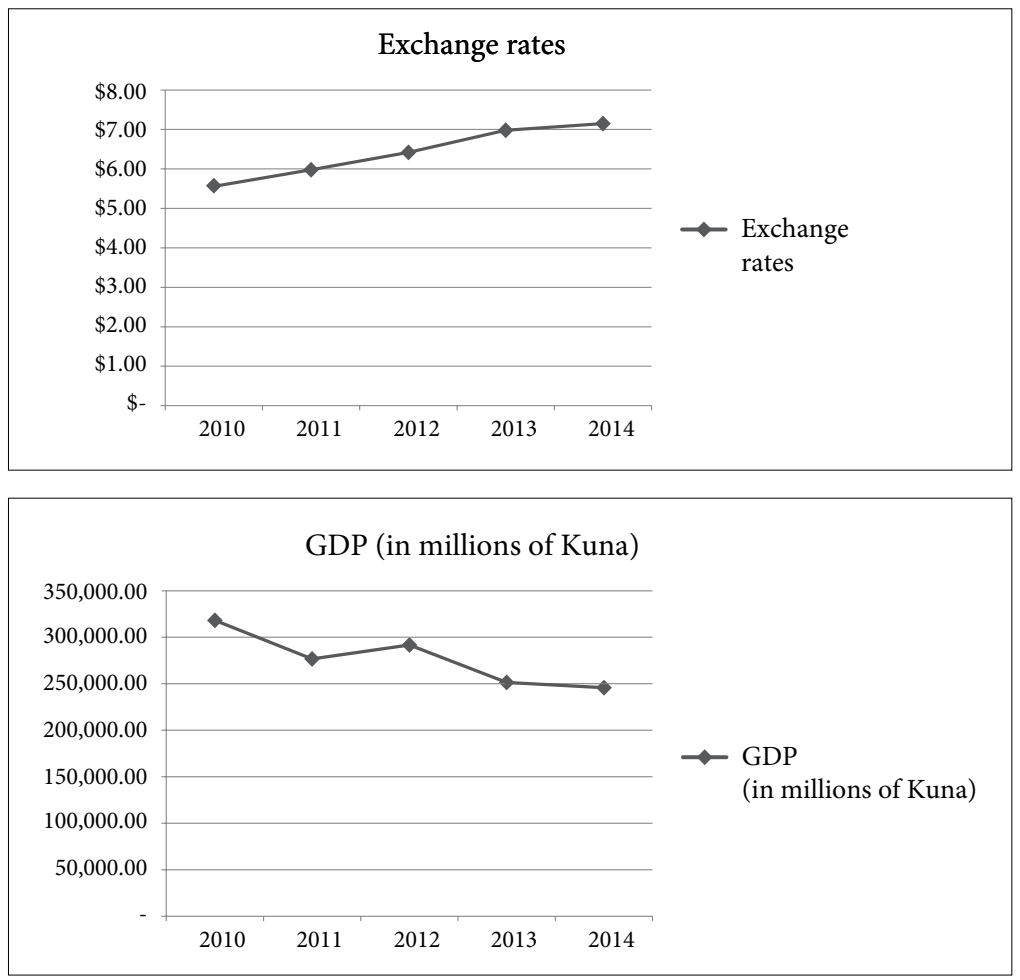

Fig. 2. Kuna exchange rate depreciation scenario impact on GDP. Source: Autors calculation

Table 4 shows the trend of GDP in case of depreciation of Kuna against the US dollar. In this case, there is a uniform reduction in GDP through the period. We conclude that there is a significant influence of exchange rate on the rate of GDP in the short term.

Table 5 shows the scenario of a rise in the price level, and the impact of inflation on the growth of GDP. In this case, there is a decrease in inflation, and this scenario follows the impact of exchange rate movements in GDP. 
In this scenario is shown increase in the level of inflation, and it examines the impact of such an increase in inflation to GDP (Fig. 3).

Table 5. The scenario of increasing inflation impact on GDP

\begin{tabular}{lrrrrr}
\hline & 2010 & 2011 & 2012 & 2013 & 2014 \\
\hline Inflation & 4.20 & 4.41 & 4.63 & 4.86 & 4.95 \\
\hline GDP (in millions of Kuna) & $330,954.00$ & $288,463.00$ & $307,793.00$ & $267,486.00$ & $295,875.00$ \\
\hline
\end{tabular}

Source: Autors calculation.
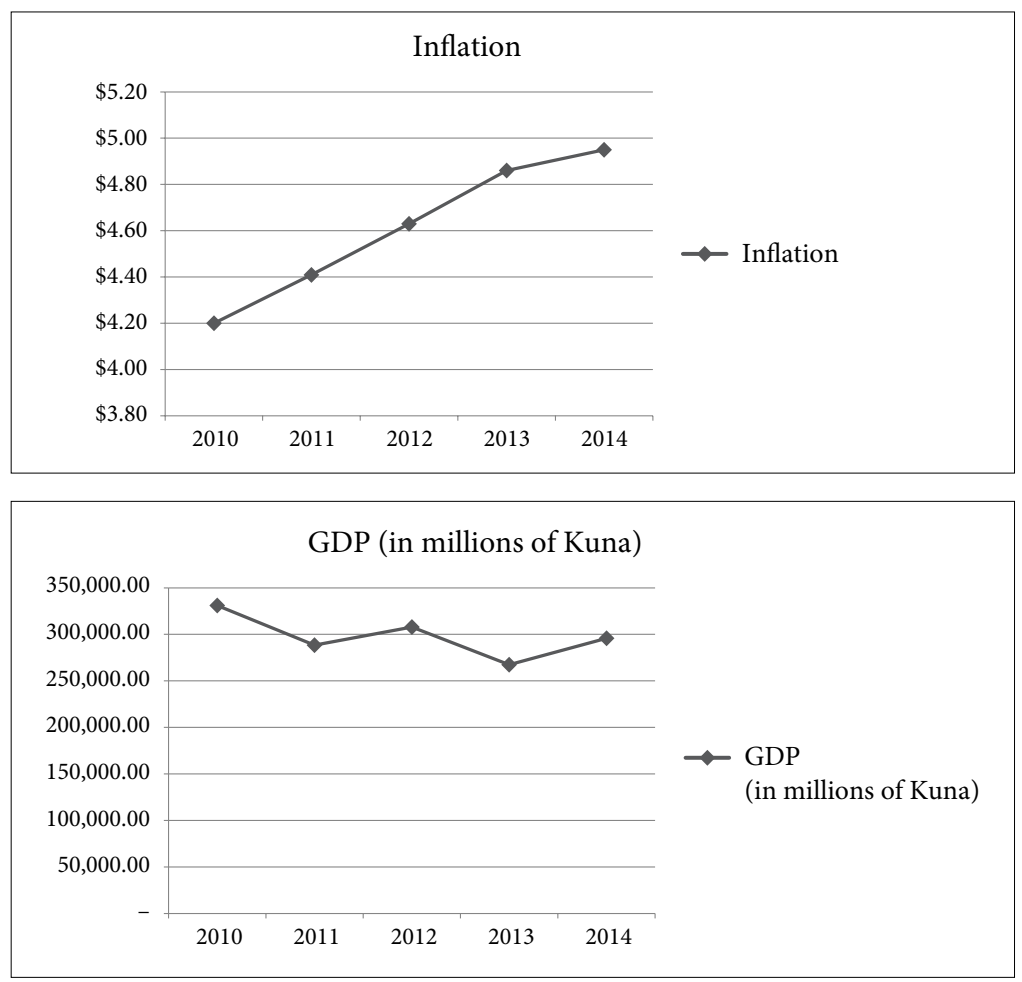

Fig. 3. The scenario of increasing inflation impact on GDP. Source: Autors calculation

Table 5 showing increasing levels of inflation observed through the observed period and its impact on GDP in that period. According to the chart on Figure 2, we can see that in the event of an increase in inflation from 4 to $5 \%$ in a given period, a decrease in GDP is registered. However, Table 6 shows the flow of GDP with respect to reducing the level of inflation from 3 to $2 \%$. Shown on the chart, we see that the growth of GDP is not significantly changed or line chart is almost identical to the graph in Figure 3. Therefore we draw the conclusion that inflation does not affect significantly the growth of GDP during the given period, or based on specific scenarios, GDP does not change direction, regardless of the level of inflation trends. 
Table 6 shows the scenario of inflation drop and associated impact on the growth of GDP. In this scenario price level decline impact on GDP is assessed (Fig. 4).

Table 6. Scenario of the reduction in the level of inflation and the impact on GDP

\begin{tabular}{lrrrrr}
\hline & 2010 & 2011 & 2012 & 2013 & 2014 \\
\hline Inflation & 3.15 & 2.99 & 2.84 & 2.69 & 1.95 \\
\hline GDP (in millions of Kuna) & $324,723.00$ & $283,758.00$ & $305,616.00$ & $265,844.00$ & $245,587.00$ \\
\hline
\end{tabular}

Source: Autors calculation.
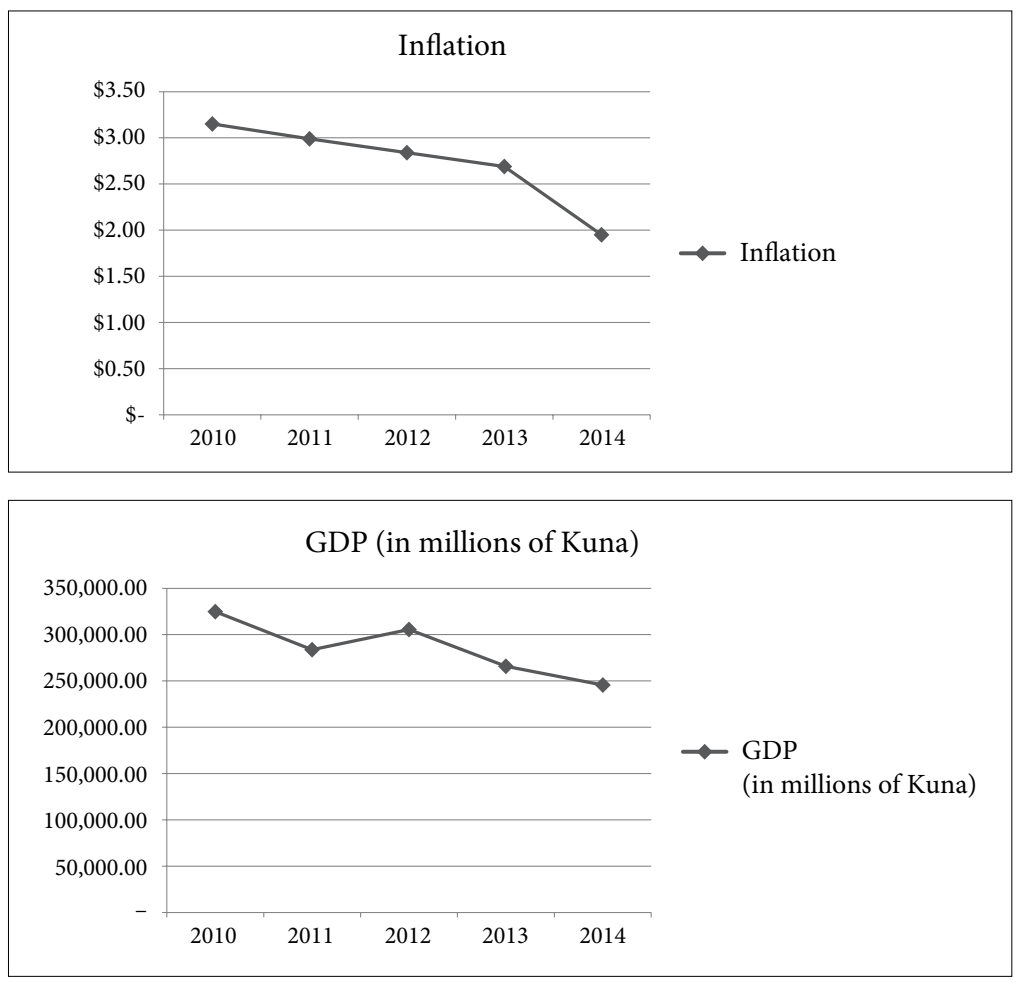

Fig. 4. Scenario of the reduction in the level of inflation and the impact on GDP. Source: Autors calculation

The data for the CGE model are based on historical data for the Croatian economy until 2009. The results presented in the tables above represent the model projections for 2010 and other years in the future. From the table 6 we can observe that a drop in the GDP follows a drop in inflation. Modern macroeconomic theory (inflation targeting particularly) would follow a different logic, i.e. that a drop in inflation should be followed by an increase in the level of production. In Croatia, however low rate of inflation is associated with high levels of unemployment (Phillips curve environment). Because of the Phillips curve and the Golden triangle law (Škare 2010) a fall in the price level cause a rise in the unemployment and thus production drop through a decline in the personal consumption level. 
Figures 5 and 6 shows the actual values for 2010 and projection values derived from the created scenarios using CGE model.

Figures 5 and 6, show the estimate of GDP, which is made in this model and the actual value of GDP for a given observed year. From these two charts, we see that there are very small deviations of the estimated value from the actual value, which brings us to the conclusion that the model is working efficiently. Actually, this brings us to the conclusion that the model results are in line with the actual situation, and we can rely on long-term assessment of trends in GDP, which have made in this model.

In the study, we show a variety of potential scenarios and their impact on the Croatian economy. For these scenarios, we can conclude that the reduction in the currency exchange rate has a positive impact on GDP. In the short term, that reduction has an impact on GDP growth. Likewise, in the reverse scenario of increasing dollar exchange rate, there is a decrease in GDP and a negative impact on the economy. What we can conclude from the following scenario presented, is a very small effect of changes in inflation to GDP. From the presented scenarios, we see that even with the reduced level of inflation but also with increasing price

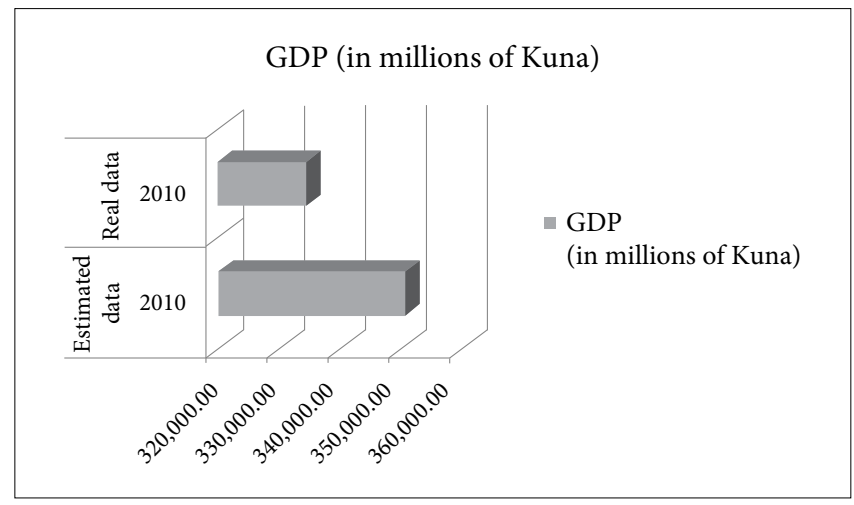

Fig. 5. Comparative review of simulated and actual GDP for 2010 at an exchange rate $1 \mathrm{USD}=5.50 \mathrm{Kn}$. Source: Autors calculation

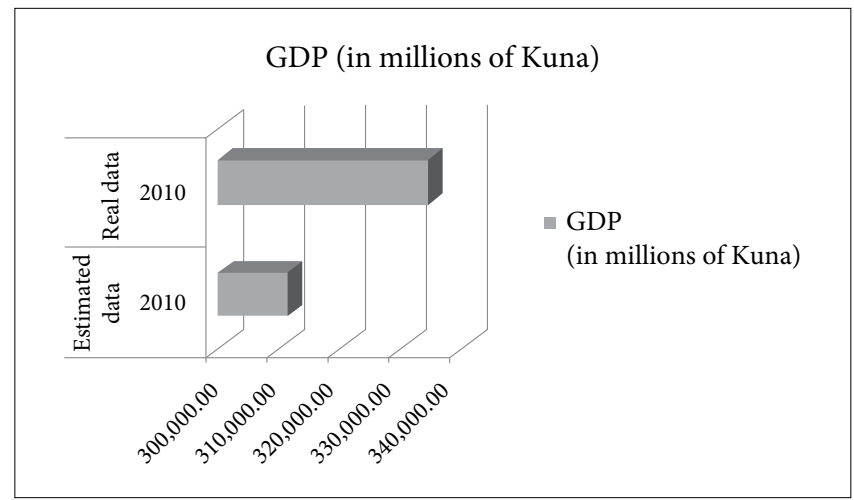

Fig. 6. Comparative review of simulated and actual GDP for 2010 at the rate of inflation of $1.1 \%$. Source: Autors calculation 
level, model estimate well movements in GDP. From this we can conclude that inflation does not have major impact on GDP, or that to a rapid increase in the price participants in the economy very quickly adapt and somehow ignore its impact.

What we see on the charts, 5 and 6, is that there are relatively small deviations of actual values in relation to estimated values from the model. On this basis, we conclude that there is a very accurate projection of the trends of observed values of certain variables in the future. The mere congruence of the estimated values and actual values allows us to reach a conclusion about the possibility of using CGE models to assess the effects of other parameters for the Croatian economy. Using this model would allow easier and better preparation for the upcoming crisis and thus facilitate the adoption of plans for economic policy and a simpler adaptation of crisis conditions.

\section{Conclusion}

The advantage in using CGE models for Croatia is precisely what these models are intended along with all the limitations placed specifically for developing countries and transition economies. The advantage of these models is that with the existing restrictions in the model, it is possible to use it in condition of incomplete data. As Croatia is a "young", emerging country and there are limitations in long time-series data, CGE models in this case provide credible results with minimal data. These models, simplifies the functioning of the economy, in the way that determines the existence of a state, with two sectors and three products. Three products are imported good, export good and domestic product. It is assumed that there is a consumer who receives all the income. The country is small in world markets, facing fixed world prices for exports and imports.

After introducing all the above limits, we set up the conditions of equilibrium. Solving CGE model's demands to bring the model into balance and simulating for potential external shocks observe their effects on other variables in the model. An important feature of CGE models is the calibration of the model. To successfully design a CGE model takes a few steps. Firstly, it is necessary to determine the structure of the general model. After that we determine the forms of certain functions that are selected for production and demand side. The most commonly used is the Cobb-Douglas function, the linear expenditure system (LES) or a function of constant elasticity of substitution (CES) function. At the end, we estimate parameter values for each function, which must be derived. Ideally, all parameters in the CGE model must be econometrically estimated, but in practice, it is usually impossible due to lack of data, the size and number of parameters in the model, and the need for sophisticated measurement techniques. That's why the most commonly used procedures for estimating the parameters in the model is calibration. Calibration process assumes that the model parameters are identified based on an observation of the overall economy. An observed economy is under the balance assumption or "benchmark" equilibrium. In practice, this balance is achieved by using equilibrium data from the social accounting matrix. Calibration process ensures that model parameters will be specified in a way to reproduce the default equilibrium solution. When the parameters of the model are calibrated, the model is finished and can be exposed to different shocks, which are referred to as simulations. 
A very important feature of the calibration is that the specification of the model is not statistically tested due to the deterministic procedure in deriving parameter values from the database. This approach uses a key assumption that the data from the database represent balanced economy that has been observed. This assumption is met using a social accounting matrix designed to ensure balance in the model. The main advantage of the calibration model is the exceed restrictions of the data used in the model. Even with the incomplete data generation process we can construct a complete model. These data can be used from a single observation that in the econometric model is not the case. This feature is very important for countries in transition with significant restraints in data availability.

The main critic from econometric researcher's aims at the inclusion of the state in the model. This implies unreliability of data, model bias from data for the selected year and the limited model structure. Uncertainty of data is a very big problem with CGE models, especially because the value of the parameters is very important for later determination of results from different simulations. Here, the main problem is that most of the data is derived from databases, but other data are derived from external sources (mostly data on the elasticity of substitution). The biggest problem for those data is they are estimated under various assumptions. This precisely is the problem of unreliability of such data.

Another drawback is related to the quality of the data selected that directly affects the quality of the whole model. In econometric models, stochastic distribution is trying to reduce errors in measuring endogenous and exogenous variables in the model. However, in the calibration process is assumed that stochastic distribution is zero, which leads to that calibration parameters must absorb all the errors occurring in the data for the selected base year. Furthermore, a social accounting matrix is not always in equilibrium, or the sum of rows is not equal to the total sum of the column, which also leads to some error that occurs in the process of bringing matrix into balance.

Limitations of the model structure as the third disadvantage of calibration is related mainly to a functional form model. That is the main drawback since the number of parameters that define calibration cannot be greater than the number of equations in the model. To solve this problem, there are several solutions, and one of these approaches is that parameter estimation is based on data from multiple years and not just on a date from a base year.

The application of research results will enable understanding of how potential external shocks may affect the Croatian economy, which will enable high-quality information base for a possible response to the global economic crisis. Application of research results can go into further development of the CGE model extending it to more sectors and adding more external and internal variables. The developed model is a simplified representation of the economy, so it is very easy on the results of the simplified model to determine the direction of future model development, its expansion into new sectors and new variables. Using this model proved to be very important for making policy decisions in small transition countries, having important policy implications in external shock's vulnerability conditions. General equilibrium model that we developed and tested for Croatia proved to be accurate and efficient in estimating major economic trends within the Croatian economy. Our study results show that emerging and transitional countries with significant data constraints should use CGE models for successful policy design. 


\section{Acknowledgments}

We are grateful to the two anonymous reviewers on their valuable suggestions and insights.

\section{References}

Akkemik, K. A. 2012. Assessing the importance of international tourism for the Turkish economy: a social accounting matrix analysis, Tourism Management 33(4): 790-801. http://dx.doi.org/10.1016/j.tourman.2011.09.002

Burkhard, H.; Mausner, A. 2005. Dynamic general equilibrium modelling - computational methods and applications. Berlin: Springer.

Baležentis, A.; Baležentis, T.; Valkauskas, R. 2010. Evaluating situation of Lithuania in the European Union: structural indicators and MULTIMOORA method, Technological and Economic Development of Economy 16(4): 578-602. http://dx.doi.org/10.3846/tede.2010.36

Brown, D.; Kubler, F. 2008. Computational aspects of general equilibrium theory. Berlin: Springer.

Channing, A.; Robinson, S.; Tarp, F. 2001. Parameter estimation for a computable general equilibrium model: a maximum entropy approach. Trade and Macroeconomics Division, International Food Policy Research Institute, Washington, USA.

Citanna, A.; Donaldson, J.; Polemarchakis, H.; Siconolfi, P.; Spear, S. E. 2005. Essays in dynamic general equilibrium theory. Berlin, Heidelberg: Springer. http://dx.doi.org/10.1007/b138734

Čižmešija, M.; Petar, S. 2010. Assessing Croatian GDP components via economic sentiment indicator, Ekonomska istrazivanja - Economic Research 23(4): 1-10.

Devarajan, S.; Delfin, S. G.; Lewis, J. D.; Robinson, S.; Sinko, P. 1997. Simple general equilibrium modeling. London: Cambridge University Press.

Essama-Nssah, B. 2004. Building and running general equilibrium models in eviews. The World Bank, Washington DC. http://dx.doi.org/10.1596/1813-9450-3197

Griffits, W. E.; Hill, R. C.; Lim, G. C. 2008. Using eviews for principles of econometrics. Wiley.

Hsing, Y. 2011. Macroeconomic variables and the stock market: the case of Croatia, Ekonomska istrazivanja - Economic Research 24: 41-50.

Huseyin, S. 1996. Social accounting matrix (SAM) and its implications for macroeconomic planning. Development Project Planning Centre (DPPC), Bradford, UK.

Lange, G.; Schade, K.; Ashipala, J.; Haimbodi, N. 2004. A social accounting matrix for Namibia, a tool for analysing economic growth, income distribution and poverty. Namibian Economic Policy Research Unit, Windhoek, Namibia.

Kim, K. 2011. Ex-ante evaluation of a targeted job program: hypothetical integration in a social accounting matrix of South Africa, Economic Modeling 28(6): 2683-2690. http://dx.doi.org/10.1016/j.econmod.2011.08.008

Lofgren, H.; Lee Harris, R.; Robinson, S. 2002. A standard computable general equilibrium (CGE) model in GAMS. International food policy research institute.

Llop. M. 2012. The role of saving and investment in a SAM price model, Annals of Regional Science 48(1): 339-357. http://dx.doi.org/10.1007/s00168-010-0403-7

Mitra-Kahn, B. H. 2005. General equilibrium theory, its history and its relation (if any) to the market economy. London: City University.

Mitra-Kahn, B. H. 2008. Debunking the myths of computable general equilibrium models. London: City University.

Moore, J. C. 2007. General equilibrium and welfare economics. Berlin, Heidelberg, New York: Springer. 
Podvezko, V.; Podviezko, A. 2010. Dependence of multi-criteria evaluation result on choice of preference functions and their parameters, Technological and Economic Development of Economy 16(1): 143-158. http://dx.doi.org/10.3846/tede.2010.09

Santos, S. 2005. Social accounting matrix and the system of national accounts: an application. Technical University of Lisbon.

Senay, O. 1998. Disinflation dynamics in an open economy general equilibrium model. University of York.

Smets, F.; Wouters, R. 2002. An estimated stochastic dynamic general equilibrium model of the Euro Area. European Central Bank.

Studenmud, A. H. 2001. Using econometrics and eviews software package. Addison Wesley.

Wing, S. I. 2000. Computable general equilibrium models and their use in economy-wide policy analysis: everything you ever wanted to know (but were afraid to ask). Boston University.

Škare, M. 2010. Can there be a 'golden triangle' of internal equilibrium?, Journal of Policy Modeling 32(4): 562-573. http://dx.doi.org/10.1016/j.jpolmod.2010.05.005

Škuflić, L.; Rabar, D.; Šokčević, S. 2010. Assessment of the efficiency of Croatian counties using data envelopment analysis, Ekonomska istrazivanja - Economic Research 23: 88-101.

Turner, K. 2012. How responsible is a region for its carbon emissions? An empirical general equilibrium analysis, Ecological Economics 76: 70-78. http://dx.doi.org/10.1016/j.ecolecon.2012.02.001

Timilsina, G.; Beghin, J. C.; Mensbrugghe, D. 2012. The impacts of biofuels targets on land-use change and food supply: a global CGE assessment. USA: Wiley-Blackwell.

Zavadskas, E. K.; Turskis, Z. 2011. Multiple criteria decision making (MCDM) methods in economics: an overview, Technological and Economic Development of Economy 17(2): 397-427. http://dx.doi.org/10.3846/20294913.2011.593291

Žvirblis, A.; Buračas, A. 2010. The consolidated measurement of the financial markets development: the case of transitional economies, Technological and Economic Development of Economy 16(2): 266-279. http://dx.doi.org/10.3846/tede.2010.17 


\section{APPENDIX A}

Table A1. Model variables

\begin{tabular}{|c|c|}
\hline Variable symbol & Variable name \\
\hline $\mathrm{E}$ & Export \\
\hline $\mathrm{D}$ & Domestic sales \\
\hline I & Import \\
\hline $\mathrm{C}$ & Price of domestic import \\
\hline $\mathrm{CD}$ & Price of domestic import before taxtation \\
\hline $\mathrm{T}$ & Exchange rates \\
\hline $\mathrm{CW}$ & Price of world export \\
\hline $\mathrm{P}$ & Producer price for composite output \\
\hline $\mathrm{CC}$ & Price of composite output \\
\hline QC & Quantity of supply of composite good \\
\hline PI & Price of import \\
\hline QI & Quantity of import \\
\hline $\mathrm{CPO}$ & Price of domestic product before taxation \\
\hline $\mathrm{CI}$ & Price of world import \\
\hline $\mathrm{PK}$ & Household consumption \\
\hline $\mathrm{PD}$ & Government consumption \\
\hline IN & Investments \\
\hline $\mathrm{CA}$ & Tariffs \\
\hline IP & Indirect taxes \\
\hline $\mathrm{PK}$ & Household taxes \\
\hline $\mathrm{RD}$ & Governement revenue \\
\hline RK & Household revenue \\
\hline SK & Household savings \\
\hline SD & Governement savings \\
\hline US & Export price \\
\hline$\alpha_{x}$ & Coefficient of elasticity \\
\hline$\varphi_{x}$ & Coefficient of elasticity of export \\
\hline te & Tax rates on exports \\
\hline td & Export quantity before taxation \\
\hline $\mathrm{tm}$ & Import tariff rates \\
\hline$\beta_{q}$ & Coefficient of aggregate function \\
\hline
\end{tabular}


Continued Table A1

\begin{tabular}{cl}
\hline Variable symbol & \\
\hline$\tau_{q}$ & Armington export coefficient \\
\hline$y t x_{k h}$ & Household income \\
\hline $\mathrm{XS}$ & Quantity of purchased products \\
\hline $\mathrm{IP}$ & Household investments \\
\hline$T R_{h h}$ & Household costs \\
\hline$m p s_{h h}$ & Household marginal save propensity \\
\hline FSAV & Fixed saving components \\
\hline$p^{q}$ & Armington function exponent \\
\hline$p^{c}$ & Price of import \\
\hline$p^{d}$ & Price demand for products that are manufactured and sold in domestic market \\
\hline$p^{x}$ & Aggregate producer price \\
\hline $\mathrm{R}$ & Numeraire price \\
\hline$p^{m}$ & Exponent of the CES function \\
\hline$p w^{w}$ & Import prices in foreign currency \\
\hline$p w^{e}$ & Total savings
\end{tabular}

Marinko ŠKARE. Professor of Economics, Editor-in-Chief of the Journal Economic Research, Member of Editorial Board of several international journals, Department Economics and Tourism "Dr. Mijo Mirković" of Juraj Dobrila University of Pula. He served as Assistant Dean for Education of the Faculty of Economics \& Tourism in Pula, Assistant Dean for International Cooperation of the Faculty of Economics \& Tourism in Pula, Main and Team Researcher on several scientific projects, Former Dean of the Faculty of Economics \& Tourism, Pula and Former Vice President for International Cooperation of Juraj Dobrila University of Pula. He has published several books and a large number of scientific papers in the area of his research interest - economic growth, welfare economics, CGE models, macroeconometrics, poverty, human capital, economics in transition, economic philosophy and monetary economics. He is a member of the American Economic Association, Royal Economic Society, Economic History Association, Economic History Society, and Association for Comparative Economic Studies.

Saša STJEPANOVIĆ is Senior Assistant at the Department of Economics and Tourism of Juraj Dobrila University of Pula. He holds a Master of Science and PhD in Economics from Univeristy of Pula. He is an author and co-author of several research papers and has been actively involved in many local development projects in Istria County. Since 2010 he is the Executive Editor of the journal Economic Research. 